\title{
両側性悪性胸膜中皮腫の 1 症例
}

西 英行, 清水 信義

\begin{abstract}
要旨
両側性同時性悪性胸膜中皮腫の診断に対して FDG-PET，対側胸腔鏡が有用であったので報告した，症例は 59 歳男性．石 綿ばく露歴があった. 健診の胸部 X 線にて左肺野に異常影を指摘された. 胸部 CT で左胸水および右胸膜の肥厚が認められ, FDG-PET では右胸膜の肥厚部に軽度集積が認められた. 左胸水細胞診にて悪性胸膜中皮腫の診断となり, 当センターに紹介 となった．左胸脘鏡検查では多数の小隆起が認められ，生検にて上皮型胸膜中皮腫の診断となった．右胸胿鏡検查では，プ ラーク様の胸膜肥厚を認め, 生検にて上皮型胸膜中皮腫の診断となった，両側 I 期（IMIG 分類）の診断で，手術療法の適応 はないと考え，現在全身化学療法中である．結語：早期病変であっても，対側にも病変がある可能性は否定できないと考え られる．FDG-PET，対側胸胿鏡検査は手術療法の適応を考える際には，考慮すべき検査であると考えられた。
\end{abstract}

索引用語：両側性悪性胸膜中皮腫, 胸垫鏡, FDG PET/CT

bilateral malignant pleural mesothelioma, thoracoscope, FDG PET/CT

はじめに

両側性同時性悪性胸膜中皮腫の報告は少ない。悪性胸 膜中皮腫は，早期に発見されることが少なく，診断時に は進行例が多い。 その解剖学的特徴から対側胸腔に進展 する可能性が否定できず，同時性であることを証明する ことが困難であるからと考えられる。

今回我々は，両側に同時発症したと考えられる症例を 経験したので報告する.

\section{症例}

患 者：59 歳. 男性. 健診の胸部 X 線にて異常陰影を 指摘された.

喫煙歴：なし.

既往歴：特記すべきことなし.

職業歴：建設業（石綿ばく露歴あり）。

現病歴：2012 年 1 月の健診にて左胸水を指摘された. 2012 年 3 月に近医にて精査が行なわれ, 胸水のヒアルロ

岡山労災病院アスベスト疾患ブロックセンター 原稿受付 2012年 9 月 12 日

原稿採択２012年11月20日
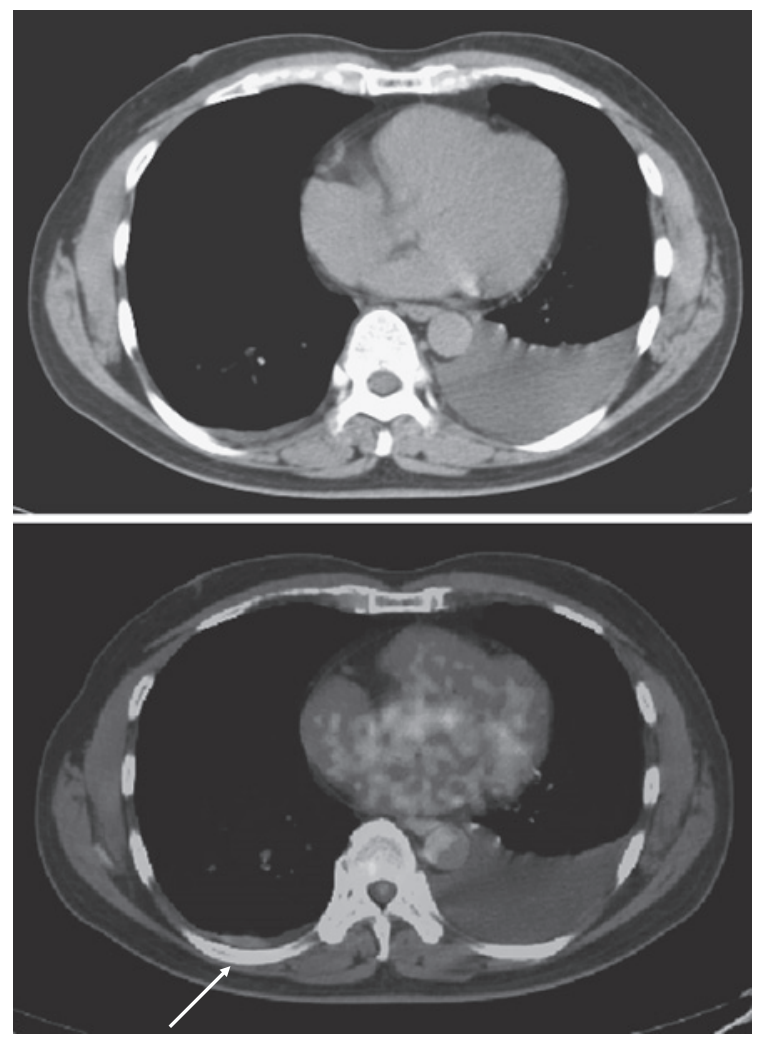

Fig. 1 FDG PET/CT. Accumulation was recognized in the pleura on the right side (white arrow). There was no accumulation at other sites. 

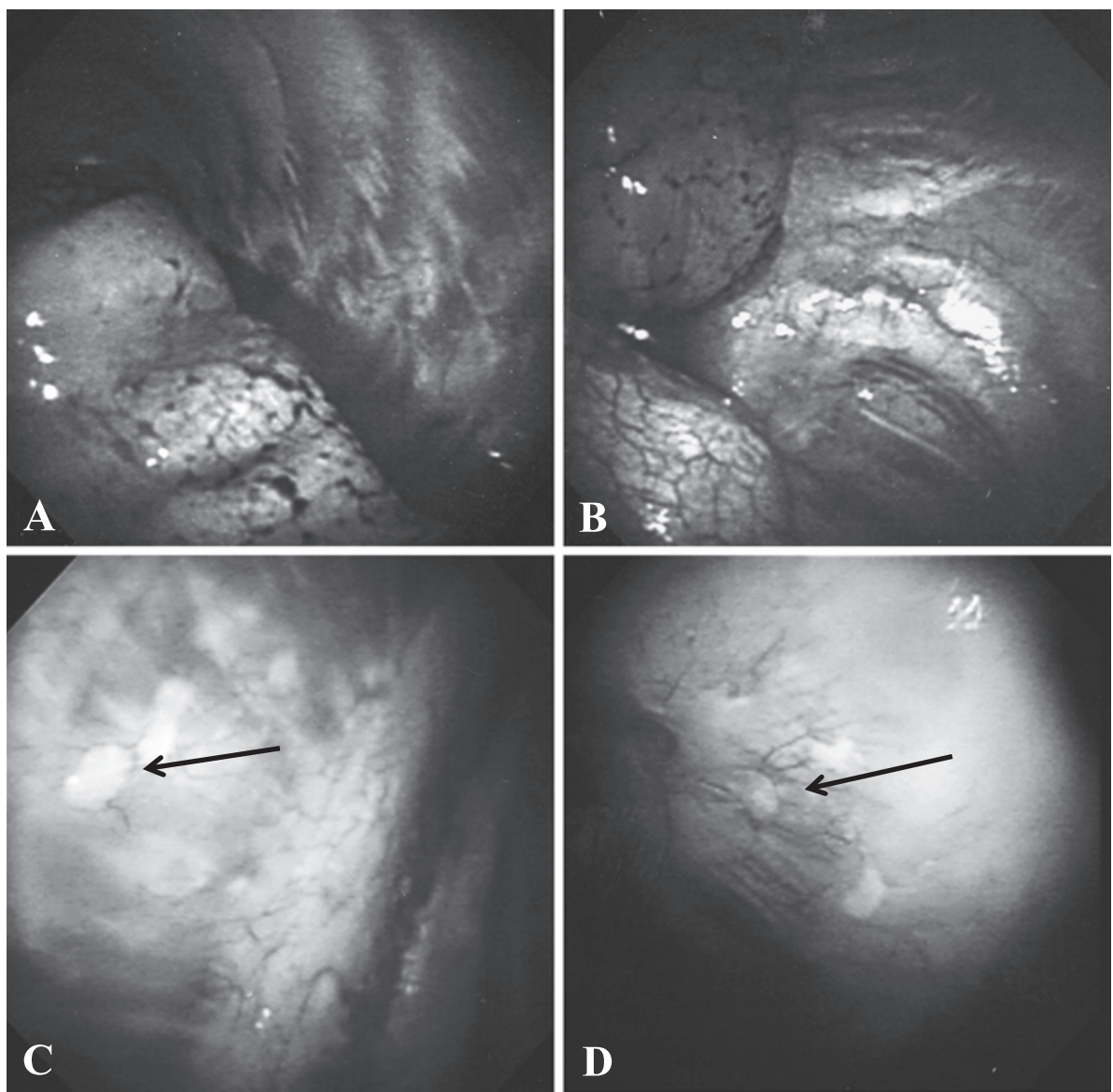

Fig. 2 Thoracoscopic findings on the left side showed pleural effusion (A), and multiple small nodules (C, D. arrows). There were no findings at the costophrenic angle (B).
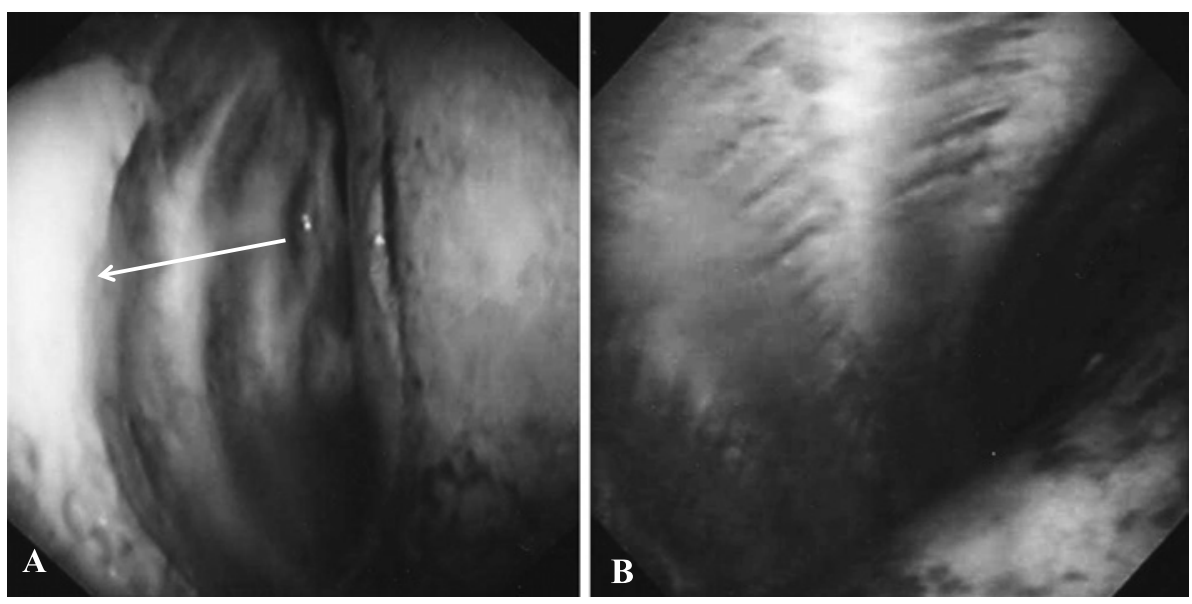

Fig. 3 Thoracoscopic findings on the right side showed pleural thickening like plaque (A. white arrow). There were no findings at other sites (B). 


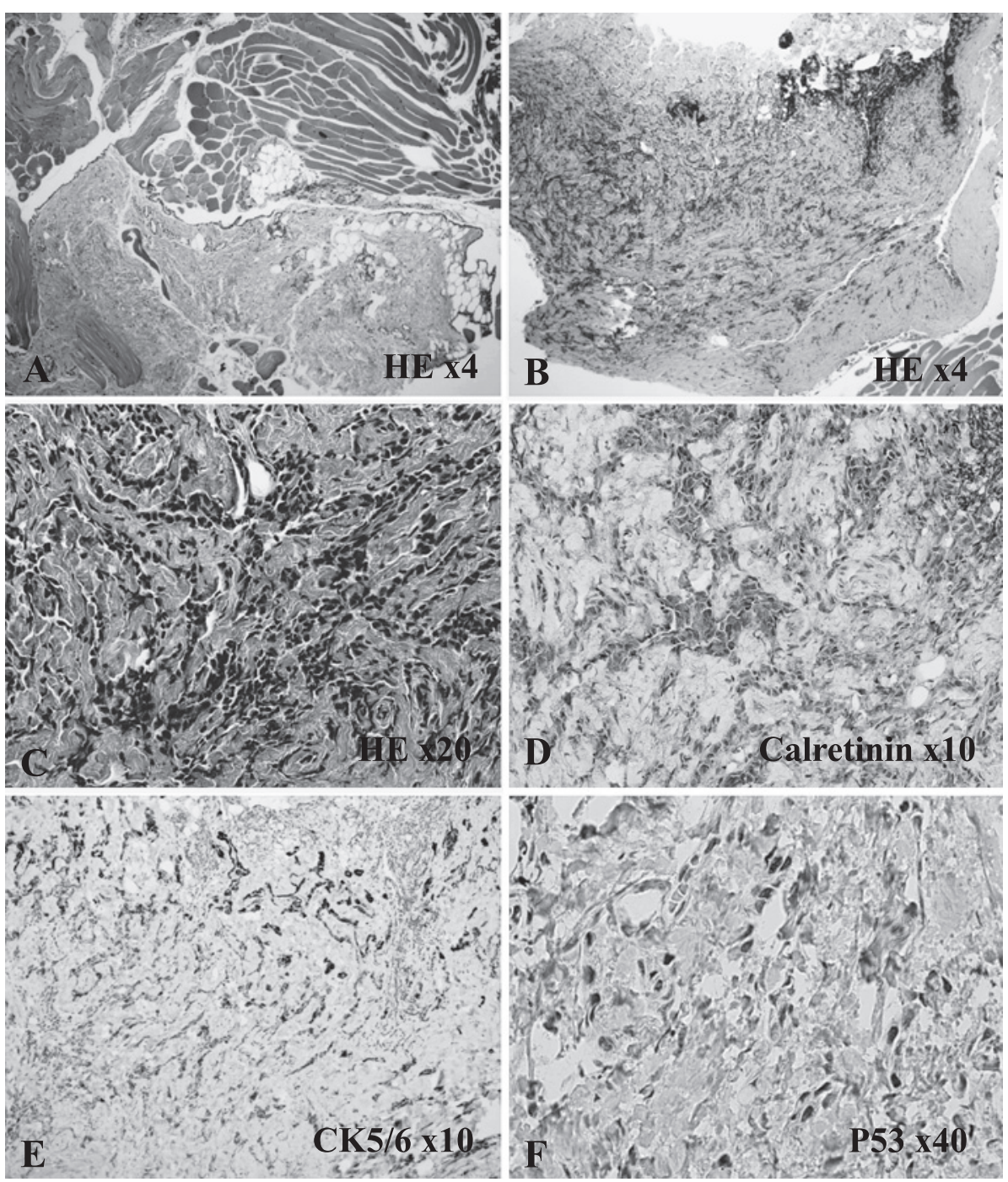

Fig. 4 Histopathological findings of the pleura on the left side showed a sheet of epithelioid cells infiltrating between layers of collagen (A, B, C). Immunohistochemical findings showed a positive reaction for Calretinin (D), CK 5/6 (E), and P53 (F).

ン酸 $130430 \mathrm{ng} / \mathrm{ml}$, 細胞診は Class V で, 胸膜中皮腫が 強く疑われた. FDG-PETでは左胸膜への集積は認めら れず，右背側胸膜に軽度の集積 $(S U V \max =1.9)$ が認め られた Fig. 1). 治療目的で当センターに紹介となった.

来院時現症 : 体温 $36.4^{\circ} \mathrm{C}$, 血圧 $139 / 88 \mathrm{mmHg}$, 脈拍 78/分, 整, SpO2 99\% (room air). 身体所見上特記すべ きことは認めなかった.

来院時検査所見：血液生化学検査では, 特に異常な值 は認められなかった，血清中の腫瘍マーカーの上昇も認 めなかった。

胸部単純 $\mathbf{X}$ 線写真 : 左肋骨横隔膜角の鈍化を認め, 左 胸水貯留が疑われた。
胸部造影 CT 写真 : 左胸腔には胸水を認めたが, 胸膜 の肥厚や腫瘤は認めなかった，右胸腔には胸水は認めな いが，肺底部背側に軽度の胸膜肥厚を認めた。

左胸水検查所見：胸水中の腫瘍マーカーのシフラが $21.6 \mathrm{ng} / \mathrm{ml}$ ，ヒアルロン酸が $115000 \mathrm{ng} / \mathrm{ml}, \mathrm{SMRP}$ が $15480 \mathrm{nmol} / 1$ と上昇が認められた. 胸水細胞診では, 類円 形核で小型核小体の見られる細胞が球状・乳頭状・花弁 状の集塊を形成しており，それぞれの細胞異型はそしい が,ほとんどが集積した集塊を形成していた. Calretinin, CAM5.2, WT-1, p53, CK5/6, AE1/AE3, EMA が陽性, CEA, TTF-1, Napsin A が陰性となり, 悪性胸膜中皮腫 が強く疑われた。 


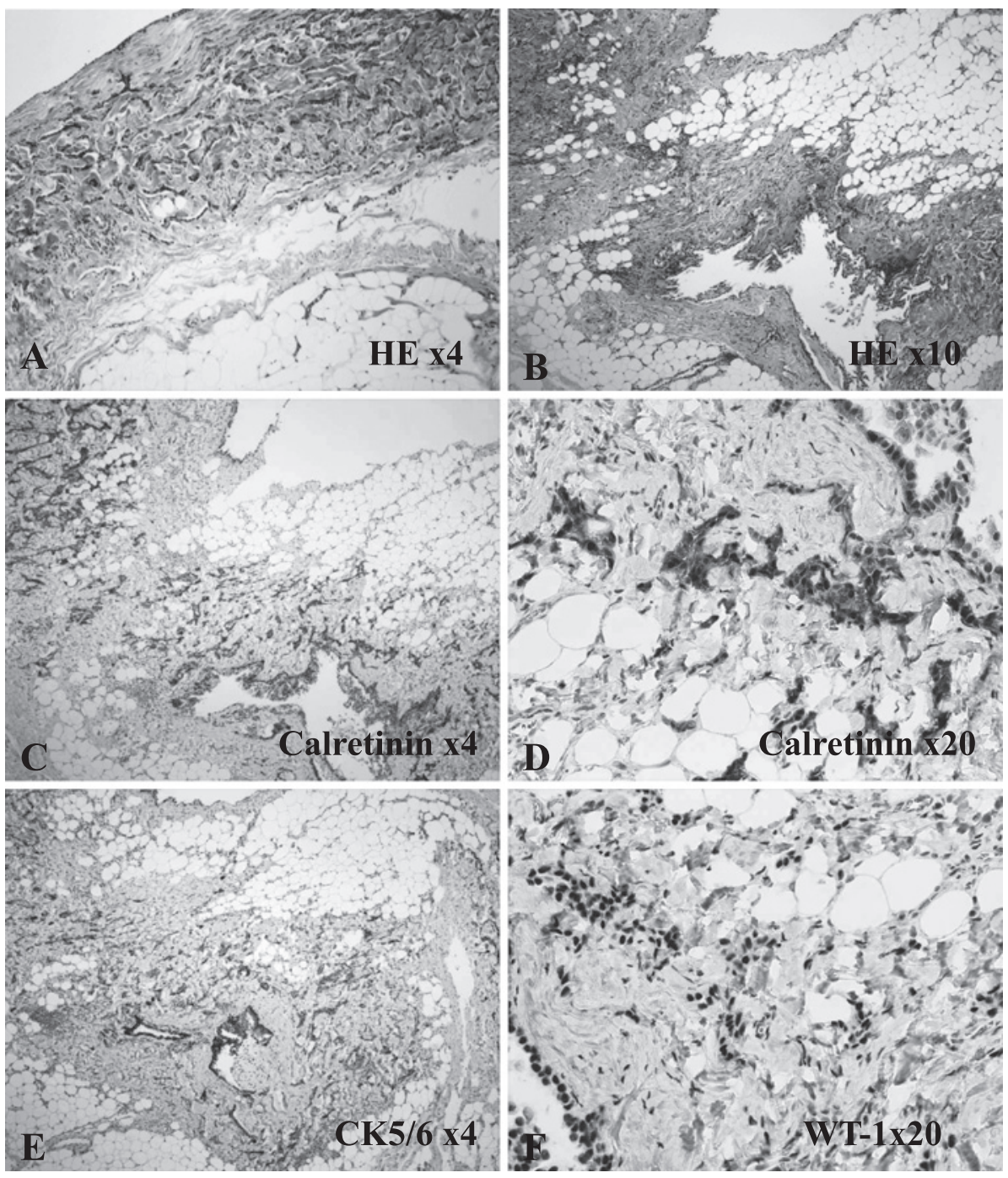

Fig. 5 Histopathological findings of the pleura on the right side showed epithelioid cells with a peudoglandular structure infiltrating between layers of collagen (A, B). Immunohistochemical findings showed a positive reaction for Calretinin (C, D), CK 5/6 (E), and WT-1 (F).

左胸腔鏡検查所見：局所麻酔下に第 7 肋間, 中腋下線 上にポートを設け, 胸腔鏡検査を行った。肺の癒着は認 められず，中等量の胸水を認めた。壁側胸膜に白色斑状 の小結節を認め, 生検を行った（Fig. 2).

右胸腔鏡検查所見 : 左胸腔鏡検查とは別の日に, 局所 麻酔下に第 7 肋間, 中腋下線上にポートを設け, 胸腔鏡 検查を行った．胸水は認めなかった．画像上胸膜肥厚が 疑われた部位にプラーク様の隆起を認め, 生検を行った. 他の部位に異常所見を認めなかった（Fig. 3).

病理組織診検査所見 : 左胸膜; 脂肪織を伴った線維増 生巣内に, 中皮細胞の索状の浸潤様増殖像が認められた.
この上皮様細胞は, 免疫組織化学検査では, Calretinin, CK5/6, WT-1, CAM5.2, CKAE1/3 が陽性, TTF-1, CEA, Napsin A が陰性となり上皮型胸膜中皮腫の診断となっ た (Fig. 4). 右胸膜 ; 肥厚した胸膜の膠原線維間に扁平か ら小型多角形の中皮細胞が偽腺管を形成し，一部脂肪織 まで浸潤していた，免疫組織化学検査では, Calretinin, CK5/6, WT-1 が陽性，TTF-1，CEA，Napsin A が陰性 となり上皮型胸膜中皮腫の診断となった（Fig. 5).

両側とも, IMIG 分類 I 期の上皮型中皮腫の診断とな り, 手術療法の適応はないと考元, 現在 cisplatin + pemetrexed の全身化学療法中である. 


\section{考察}

両側性同時性悪性胸膜中皮腫の報告は少ない.

我々が Pub Med および医学中央雑誌で検索したとこ ろ 8 例の報告のみであった ${ }^{1-8)}$. 解剖学的に, 対側胸腔へ は, 胸膜, 横隔膜, 心膜より直接浸潤したり, 肺実質へ は胸膜に近い部分では, 胸膜下結合織, その延長である 小葉間間質に沿いながら浸潤し，またリンパ行性，血行 性に転移したりすることも考えられ, 同時性の発症を証 明することが困難であることが，報告の少ない理由のひ とつと考えられる. 当センターでは, これまでに 135 例 の悪性胸膜中皮腫症例に診断および治療を行ってきた が, 本症例を含み診断時に両側発症していた症例は 2 例 であった. 1 例は, 組織型が肉腫型 (線維形成性)であり 進行例であったために, 浸潤および転移の可能性は否定 できない症例であった ${ }^{2)}$. 今回の症例では, 両側とも早期 病変と考えられ, 少なくとも, CT P FDG-PETより直接 浸潤した可能性は極めて低いと考えられた。

今回の症例は, 明らかな石綿ばく露歴があり胸膜肥厚 が存在することが予想されるため, 有意な集積ではない ものの, FDG-PETが前医で行なわれていなければ, IMIG 分類 I 期として, 左胸膜肺全摘術を行なう予定で あった．悪性胸膜中皮腫における FDG-PET の有用性に 関しては, 多数の報告があるが, Otsuka らは ${ }^{9)}$, 原発腫瘍 の進展, 再発診断およびリンパ節の評価に有用であると 報告している. また, 奥村らは ${ }^{10)}$, Stage I-II 期と考えら れた症例 5 例のうち, 対側に転移を認めた症例が 1 例あ り, 胸膜肺全摘術の侵襲を考えても術前評価にFDGPET は有用な検査と報告している. 今回の症例では, 左 側の病変では FDG-PET の集積が認められず，胸水が貯 留していたことが, 診断につながったが, FDG-PETが, 右側の胸腔鏡検査を行なうきっかけとなり, 無用な手術 が回避される結果となった。手術療法を考える際には, FDG-PET, 対側胸腔鏡検査の重要性 ${ }^{10-12)}$ を考えさせられ た.

\section{文献}

1. 佐野公康, 中村博式, 今尾要浩, 安田成雄, 加藤達雄, 森
川洋匡，他. 同時性両側性悪性胸膜中皮腫の 1 例. 肺癌 2006; 46: 676 .

2. 西 英行, 玄馬顕一, 小崎晋司, 岸本卓巳. 両側に同時発 症した悪性胸膜中皮腫の 1 例. 肺癌 2004; $44: 274$.

3. 矢野敬文, 市川洋一郎, 田中二三郎, 加地正郎, 西村 剛, 入江康司. 両側性にびまん性斑状, 網状影を呈した悪性胸 膜中皮腫の 1 症例. 日胸疾会誌 1984; 22: 690-5.

4. Golla B, Singh SP, Pinkard NB, Klemm KM, Nath H. Case of the season. Rapidly fatal bilateral malignant mesothelioma. Semin Roentgenol 1998; 33: 306-8.

5. Land I, Knolle H. Bilateral pleural mesothelioma-case report. Z Gesamte Inn Med 1990; 45: 463-5.

6. Mannes GP, Gouw AS, Postmus PE. Bilateral pleural effusion due to malignant mesothelioma, diagnosed by means of immunostaining. Eur Respir J 1990; 3: 833-6.

7. 沖塩協一, 川口知哉, 上野清伸, 武本優次, 安宅信二, 小 河原光正, 他. 6 年間の経過を辿り, 両側胸膜に進展のみ られた悪性胸膜中皮腫の 1 剖検例. 肺癌 1998; 38: 380-1.

8. 片山信之, 富岡洋海, 岡崎美樹, 長谷川幹, 坂本広子, 石 原享介, 他. 気管支ファイバースコープを用いた胸膜生検 で診断が確定した両側性悪性胸膜中皮腫の 1 例. 気管支 学 1992; 14: 136-41.

9. Otsuka H, Terazawa K, Morita N, Otomi Y, Yamashita K, Nishitani H. Is FDG-PET/CT useful for managing malignant pleural mesothelioma? J Med Invest 2009; 56: 1620.

10. 奥村好邦, 田中文啓, 長谷川誠紀, 福岡和也, 中野孝司. 墨性胸膜中皮腫の【診断と治療】悪性胸膜中皮腫の術前評 価と手術適応. 胸部外科 $2007 ; \mathbf{6 0}: 25-9$.

11. Alvarez JM, Ha T, Musk W, Robins P, Price R, Byrne MJ. Importance of mediastinoscopy, bilateral thoracoscopy, and laparoscopy in correct staging of malignant mesothelioma before extrapleural pneumonectomy. J Thorac Cardiovasc Surg 2005; 130: 905-6.

12. 奥村好邦, 長谷川誠紀, 田中文啓, 近藤展行, 多久和輝尚, 橋本昌樹, 他. 悪性胸膜中皮腫に対する外科的手術適応に ついて (腹腔鏡・縦隔鏡・対側胸腔鏡による術前診断). 日内視鏡外会誌 2008; 13Suppl: S357. 


\title{
A case of bilateral malignant pleural mesothelioma
}

\author{
Hideyuki Nishi, Nobuyoshi Shimizu
}

Main Center for Asbestos-related Disease for Diagnosis and Treatment, Okayama Rosai Hospital, Japan

A case of bilateral malignant pleural mesothelioma diagnosed after FDG PET/CT and bilateral thoracoscopy is reported. A 59-year-old man who had a history of asbestos exposure was admitted to another hospital because of pleural effusion on the left side on a plain chest radiograph. Computed tomography revealed pleural effusion on the left side, and pleural thickening of the visceral pleura on the right side. FDG PET/CT demonstrated uptake in the pleura on the right side. There was no accumulation at other sites. After a diagnosis of malignant pleural mesothelioma based on cytological examination, he was referred to our center. Thoracoscopic findings revealed multiple small nodules on the left side. Biopsy was performed, leading to a diagnosis of epithelial mesothelioma. Thoracoscopic findings showed pleural thickening like plaque on the right side. Biopsy was performed, leading to a diagnosis of epithelial mesothelioma. We considered that there was no indication for surgery because it was bilateral malignant pleural mesothelioma stage I. Chemotherapy is now being performed.

Conclusion: We encountered a patient with bilateral malignant pleural mesothelioma with bilateral stage I. Therefore, we considered the importance of FDG PET/CT and bilateral thoracoscopy before deciding on surgical treatment.

(C) The Japanese Association for Chest Surgery (JACS) 